\title{
THE IMPACT OF MANIPURI DANCE IN THE ROYAL COURT OF TRIPURA
}

\section{Sudeshna Singha ${ }^{* 1}$ 叫}

${ }^{* 1}$ Research Scholar, Santiniketan Visva-Bharati University, West Bengal, India

DOI: https://doi.org/10.29121/granthaalayah.v9.i3.2021.3785

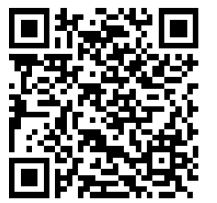

Article Type: Research Article

Article Citation: Sudeshna Singha. (2021). THE IMPACT OF MANIPURI DANCE IN THE ROYAL COURT OF TRIPURA. International Journal of Research -GRANTHAALAYAH, 9(3), 360-367.

https://doi.org/10.29121/granthaa layah.v9.i3.2021.3785

Received Date: 09 March 2021

Accepted Date: 31 March 2021

Keywords:

Tripura

Dance

Royal Court

\begin{abstract}
Manipuri people are a small group of Tripura. During the time of the Maharaja's these people's song and music attained a very special status. Firstly, it was royal palace centered, secondly, in various places of Tripura in the Manipuri dominant areas and in their temples, mandaps or at various festivals. According to many writers it can be said clearly like a mirror the Manipuri culture touched Tripura during the tenure of Rajdhar Manikya from 1785 - 1804. And at that very same time the tenure of Manipuri king Bhagyachandra is 1759 - 61 and 1763 - 1798. The Manipuri Raas established by him later on achieved the status of Indian classical dance. In later times, Manipuri culture started influencing the royal palace right after Harisheshwari became the queen of Tripura. In that time's Agartala that means in Old Agartala, near to the royal palace for the first time Radhamadhab temple was established. The name of the Manipuri dominant areas in this Old Agartala is Nalgaria. This is where Maharani Tulsibati took birth. According to the writer Udainarayan Adhikari - "The Manipuri's who came to Tripura with Princes Harisheshwari of Manipur at the fag end of the 18th century as a result of her wedding with Rajdhar Manikya II of Tripura, were settled in a village near capital old Agartala. This village now goes by the name of Mekhlipara, because Mekhli was the Tripura name for Manipur in the days of yore. There is a small township called Ranir Bazar a few kilometres east of Old Agartala or Khayerpur. It was founded by the Manipuri queen Maharani Tulsibati. Her parents lived at Nalgadiya a little east of Ranirbazar. So she founded this bazaar or township in order to develop this area. The name Ranirbaazar reminds us that it was founded by a Rani (Maharani Tulsibati).
\end{abstract}

\section{INTRODUCTION}

The traditional Chowdyo Devata Mandir is situated at Khayerpur. According to the historians during the tenure of Second Rajdhar Manikya, the singer, dancer and attendants came to Tripura along with Harisheshwari, among one of them performed the Maharaas event. But there are no specific mention of Raasdhari, Sutradhari and Gopis. But it is a matter of fact that the maharaas which takes place every year during the full moon day of the month of Kartik in the Radhamadhab temple was started from that time onwards, during the reign of Second Rajdhar Manikya. Every year, in the Radhamadhab temple at Old Agartala Maharaas festival is held. In the book 'Takhengi Puwarida Manipuri, the writer mentions that -"Anishuba Rajdhar Manikyagi machanupa ahan Ramganga Manikya meiteichanu

(C) 2021 The Author(s). This is an open access article distributed under the terms of the Creative Commons Attribution License, which permits unrestricted use, distribution, and reproduction in any medium, provided the original author and source are credited. 
luhongdana konungda pushinkhi haibagi itihashki praman leite. Khrishtakumja 1804 da Ramganga Manikyana manaonupa Kashichandraga loinana Tripura ningthowgi jamidargi lam manung chanba Bishgaon khungangda matam kharani leiringeida Manipuri sanskritigi mashak khangba houkhi. Matamduda Bishgaonda Meitei khungang paktakna khundaduna leire. Ningthowgi khilat fangdrabasu Ramganga Manikyana Meitei brahmanshingna iratliba 'Madanchakra' laifamgidamak Brahmattor samppatti pibirammi."

That means, there are no evidence available, whether Second Rajdhar Manikya's son Ramganga Manikya married any Manipuri girl or not. In the year 1804 Ramganga Manikya along with his brother Kashichandra Manikya while staying in Bishgaon village under the jurisdiction of the King of Tripura came to know about Manipuri culture and learned many things. So they were very much influenced by the Manipuri culture so that they have given the land in the name of God called Madanchakra, worshipped by the Brahmins of that village. Therefore along with the experience of the practice of the Manipuri culture inside the royal house by the queen, the activities of the people of the villagers of Bishgaon made a stronger bonding with her two sons.

In the book, "Tripurar Manipuri Praja, the writer more deeply writes that -" King Bhagyachandra on his way to pilgrimage gave his daughter to Rajdhar Manikya, and also gave an idol of Radhamadhab in the royal palace, perhaps for the worshipping for his daughter. Raas yatra started after the Govindaji of Manipur. King Bhagyachandra established the idol of Govindaji. Radhamadhab of this place is like the Govindaji of Manipur. So on the full moon night of the month of Kartik, raas festival takes place every year. Along with the princess of Manipur many attendants stayed back at old Agartala. They are the artists of these songs - player, singer, dancers. The official outset of Manipuri dance in this state origins from the royal palace." In relevance it can be said that the Manipuri people started living in this state after the attendants of Queen Harisheshwari. The son of Maharaja Kashichandra, Krishnakishore Manikya (1830 - 49) became the king of this state. After marrying the Manipuri princes Ratnamala, he married three daughters of King Marjit Sing - Chandrakala, Bidhukala and Akhileshwari and made them the queen of Tripura. During his tenure the capital was shifted from Old Agartala to New Haveli. Manipuris used to call New Haveli as 'Aoli'. After the marriage of Brahmin daughter Purnakala, she was brought to the New Haveli. From that time onwards the relatives of Purnakala were brought to the adjacent areas of New Haveli and they were permanently settled there. Like - Radhanagar, Dhaleshwar and Abhoynagar.

In the book, 'Takhengi Puwarida Manipuri' the writer W. Birmangal mentions that -"Matamdugi raasdhari shingi manungda moirangthem babuni shaknairaba oja ama oirammi. Takhen konungda chatnabi pathap ama leibagi maramna Meitei chanurasing pumnamak pateshwari maharani oina fambal tongdringeida tangaifadana maharaaski jagoida makok chingdaba yade. Maharani Muktabali, Maharanai Rajeshwari, Mahharani Monmohini, Maharani Ratnamanjuri, Maharani Tulsibati, Maharani Bhanumati, Maharani Jatishwari, Maharani Akhileshwarina chingba pumnamakpu Radhamadhabki chahigi Raaslilagi thouramda jagoi makok chinghanhki." So every year Raas Lila takes place in this Radhamadhab temple, even taking place now also. In earlier days, all Manipuri queens of the royal palace participated in the Raas Lila of this temple. This was a custom of that time.

After the death of Maharaja Krishnakishore Manikya, his son Maharaja Ishan Chandra Manikya (1850 - 1863) became the king of Tripura. He also married Manipuri princess Moirangthenchanu Muktabali, Khumenthemchanu Chandreshwari and Koishamchanu Jatishwari. The king settled their relatives in New Haveli. From Maharaja Kashichandra Manikya to Maharaja Ishan Chandra Manikya all married Manipuri princes. With the touch of the Manipuri culture in the royal palace from the time of the Second Rajdhar Manikya, the raas yatra still continues. The Manipuri queens gradually propagated their own culture in the royal family.

Maharaja Kashichandra Manikya, Maharaja Ishan Chandra Manikya, Maharaja Bir Chandra Manikya (1862 -96), Radha Kishore Manikya (1896 - 1909), Birendra Kishore Manikya (1909 - 1923), Bir Bikram Kishore Manikya (1923 - 1947) - all of them had accepted several Manipuri princes as their queen. They have brought Manipuri dance and music, art and culture, weaving, Manipuri language, even Manipuri food have and culinary technique inside the royal palace. Planting of basil tree as a part of Vaishnab tradition, establishment of the idol of Radhamadhab and other deities inside the royal palace, and they have also arranged worshipping of them there. They used to know songs and dance as this is not a separate thing in Manipuri culture, even this is not for mere entertainment. Dance and music is an integral part of Manipuri devotion, spirituality, life style and other festivals. The kings of Tripura were the lover of music, dance, painting, photography, sculpture and essence of literature and they inspired all. They themselves used to practice and used to write songs, poems and they traversed in the diverse field of literature. They were expert at these. Therefore Manipuri dance and songs flourished in several wings with the touch of their kind heart. Colonel Mahim Chandra in his book 'Desiya Rajya' while reminiscing wrote how he spent one night about of the practice of Jhulan jagoi by Maharaja Bir Chandra Manikya. On that day King Birchandra turned into philosopher. Mahim Chandra 
wrote - I never thought that on the moon light night of the month of Vadra two things could happen simultaneously. He was deeply immersed in the thought and along with strongly doing the duty of a stern king merged together. Some writers wrote "From the time of King Bir Chandrra to Birendra Kishore was the heyday of Manipuri art and culture in Tripura." The contribution of Maharaja Bir Chandra Manikya about the spreading of Manipuri dance and music inside the palace are being analysed by L. Birmangal and Pannalal Roy -"with the interest and support of Maharaja Bir Chandra Manikya the flow of Manipuri dance and music was added to the culture of the royal palace. Maharaja Bir Chandra Manikya was a poet, lyricist and lover of art and a critique of culture. Maharaja himself used to organise Raas lila. He tried to add new things to the Manipuri tradition of art. One of the culture related educationist of that time in his essay "Swadhin Tripurar Manipuri Raas" (published in Bharati on Shraban edition in 1307 Bangabda) wrote -"King Bhagyachandra (King of Manipur) the kind of dress of gopis saw in his dream it is that kind of dress. From that time there is no change. The raas Maharaja Bir Chandra Manikya used to do that was of different kind... With the permission of the king I saw it (raas done by the king himself) and unlike previous day this time I sat nearer to the raas chakra, and there was sufficient light that day. However, today it was not that much good like the previous day. May be I sat very near or due to some other reason; I could not relish the metaphysical feeling that I have found in the previous performance. The dress today was more costly and new and many sparkling elements were added to the dresses. All the dancers today were not unmarried girls, many of them were married having a big vermillion spot in the middle of the forehead, some of them were mother to child, and at least their age shows that. In today's gestures that softness and pause was not visible rather there was hastiness in everything..."

In order to add new trend in Manipuri dance drama Maharaja Bir Chandra composed songs. One of a song is "Madanaka bane abasha tanu garagara

Chalanahu nivrita nikunje

Madhu made shatapada joichana dhaoata

Eichhe chalata manaranje.

Jhalakata charu, mayura shikhandana

Shovita mukha arabinde.

Kata kota kama charanapari rouyata

Kata chanda charanara binde.

Rupa heri lubdha jagata mandala

Rahata prem rase jagi

Adhamadham pamara das Birchandra

Rouyata bindukana lagi.

Many songs written by Bir Chandra were being staged in many programmes for a long time. It helped to elate the condition of cultural practices done in the royal family or by other artists. In reference to Jhulan festival it can be said that the origin of 'Jhulan Raas' or 'Jhulan Jagoi' is in Tripura. During the reign of Maharaja Bir Chandra in Tripura (1862 - 1896) Lai Haraoba festival took place here for the first time. The Manipuri queen Rajeshwari Devi of Bir Chandra worshipped the god Pakhangba so that their song Radha Kishore could ascend to the throne. She started Lai Haraoba for this puja. This is how this festival started in Tripura. Pakhangba temple is situated in between Motor Stand and Math Chowmuhuni at Agartala. When Maharaja Churachanda Singh came to Agartala, Lai Haraoba held here. Along with raas, Lai haraoba held here during that tenure. Therefore Maharaja Bir Chandra is the propagator of jhulan raas. Along with his patronage and untiring efforts of Manipuri dance gurus now we can enjoy the entire dance drama. At that time the dance guru in the royal palace was Moirangthem Babuni Singha. The 'Jhulan Jagoi' held in 1872 Moirangthem Babuni Singha was its dance teacher as we find in the book 'Takhengi Puwarida Manipuri' by W. Birmangal. After the first performance of jhulan raas, in 1892 Maharaja Bir Chandra Mankiya wrote lyrical book 'Shri Shri Jhulan'.

In 1870, Radha Kishore Manikya married Ratnamanjuri, the daughter of Devendra Singha who was an expelled king of Manipur living in Dhaka. It is heard that prior to the marriage Ratnamanjuri performed as Nrityangana (Makok Chingbi) in front of Radhamadhab. Ratnamanjuri was the head queen of Radha Kishore. During the time of Radha Kishore Manipuri dance, song, culture took an official form in the royal palace and to execute that a minister was appointed. That minister was stripped of his post due to negligence in his duty by the verdict of the king, which is mentioned in the book 'Tripurar Manipuri Praja'. 
"Sri Hari

R.K.Deb Barman

Memo No. 63

It has come to known that in view of the last dol and raas yatra the members of the Raj community did not perform Kirtan and etc. being aptly present there and those who were there from that community did much hastiness and the Kirtan was not performed according to the custom. In order to settle the issue the head in charge of this community Naradhwaja Thakur has been informed in a written manner. But no answer has been received yet. Not only that there has been no remedy imparted by the said Thakur. In this situation, the executive members of this community must be shifted and suspended otherwise there is no reason visible to perform the kirtan in adequate manner. Therefore Naradhwaja Thakur has been relieved from his duty and from now onwards the same power has been laid on Srijukta Jugal Kishore and Srijukta Rasamohan Thakur in order to perform the kirtan of the said community in a proper way. Both the Thakur have to keep strict vigil so that the Kirtan takes place in a proper way. The copy of this order shall be sent to the related persons.

By Order

1307 Tripurabda, $15^{\text {th }}$ Ashwin.

Naradhwaja Thakur was a minister of Tripura. The incident took place at the end of the $19^{\text {th }}$ century. It is very much clear that the kings of Tripura took the dance and music of Manipur in a very serious manner. The Raj community mentioned here is the King's own royal Kir community 'Ningthem Pala'. In Manipuri Ningthem signifies royal. The kings of Manipur have their own Kirtan team, which is known as Ningthem Pala. The kings of Tripura also had the same Ningthem Pala. There was a separate budget for this Ningthem Pala. In the 1941 budget of Maharaja Bir Bikram we get to see the names of some members belonging to the Ningthem Pala.

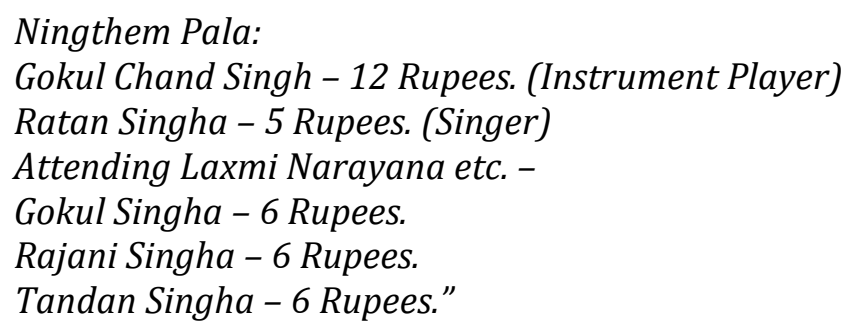

Ninghthem Pala or the Manipuri kirtan team was formed during the regime of Radha Kishore Manikya. His son, Birendra Kishore also tried to form the same kirtan team like his father. He had learned to play Mridanga in a traditional manner. It is heard that Maharaja Radha Kishore forbade his son Birendra Kishore from learning the adequate things for Manipuri kirtan as the former believed that the kind of devotion and lifestyle required learning this will not be able to meet by his son, which might cause serious sin in the course of the event.

But Maharaja Birendra Kishore performed Mahadhumel kirtan. Mahadhumel is a distinctive Nata Sankirtan. Here remains 14 Mridanga player (14 Madol) and 14 different sanchar taal is used. That Mahadhumel was performed at Radhanagar mandap. It is also known that Maharaja Birendra Kishore was one of the 14 Mridanga players in that event. As per the history of the 14 Madol players, when Sri Chaitanyadev returned from the Deccan, then many people came to see him as well as ratha yatra. This group of devotees were divided into seven groups and did kirtan. According to Vaishnab religion they are known as Saat Sampraday. In each group there are two players which totally count fourteen. They play 14 Mridanga or 14 Madol. Mahadhumel also took place during the time of Radha Kishore also. But the way Mahadhumel took place during the Birendra Kishore, the earlier lacked that grandeur. The reason is those who participated in the Mahadhumel of Birendra Kishore were the genius oja or gurus of Manipuri dance drama like - Oja (guru) Thang Kokpa, Oja Shamban Tubanba, Chaobahan mei Chamba, Oja Haoba, Oja Jogendra, Mayangbam Patan. Sarangbam Ratan, Aheibam Fopra, Oja Shibjoy, Ngangbem Ibetombi and Snakha Nitaipadasna (Jitendrajit Rajkumar). Talking about the practice of Manipuri dance and music, it is obvious to mention Rajkumar Jitendrajit Singh. He created a beautiful atmosphere at Agartala by practicing Manipuri dance and music. He is a descendant of Manipur royal family. He stayed outside Manipur. He acquainted the Manipuri people of Tripura to Manohar Sahi, who was a talented dhong kirtan performer. Here it is to be mentioned that the songs used in Manipuri natasankirtan and raas, maximum of them are being taken from the compositions of Vaishnab Mahajans. The writer 
of 'Tripurar Manipuri Praja' stated that "Maharaja Birendra Kishore Manikya wanted to give a new form to the events of Manipuri dance and music by adding new jewellery to that. For that matter I am talking some information from the book 'Tripurar Manipuri Praja' and illustrating in my own way in the following paragraphs. For example it can be said that many times Manipuri dance and music events were organised in the royal palace during his tenure. Once, Nupi (girls) pala was organised in that event. In that programme the daughters of the king participated. There the Mridanga players were garlanded with bulbs of torch which was attached to a battery and with the rhythm of Mridanga those bulbs used to falsh. This programme was a competition between the king and his elder mother Maharani. The taal was 'Kokil Priyo' taal. Maharaja himself played Mridanga and Rajkumar Buddhimanta Singh was the assistant. Rajkumar Jitendrajit Singh, Paongbom Thakur Nabakumar Singha, Tonjom Thakur Kumudbandhu Singha like stalwarts were in the team of Maharani.

Basanta Utasav was very famous inside the royal palace. In an invitation letter of Basanta Utsav in 1922-23 it is said like this -

Raj Lanchan

Agami 8/9/10/11/12 ei Magh tarikhe sangiyo progrem anusare Ujjayanta Prasad prangone Basantotsav hoibe . Tadupalakkhe aponader nimantran kora jaitechhe.

Eti - san 1332 tring 2 ra Magh

Sri Brajendra Kishore Debbarma

Karjyadhakkho

1) Atadupalakkhe parichchhad basanta rang er chinhya dharan kora banchaniyo.

2) 11-ei Magh udyan sammelane jogdan kale anugraha purbak ei card aaniben.

English term is -

On 8/9/10/11/12 Magh as per the musical programme in the courtyard of the palace Basantotsav will be held. On that occasion you are invited.

Sincerely - 1332 Tripurabda $2^{\text {nd }}$ Magh.

Sri Brajendra Kishore Debbarma.

Cashier.

1) $1 /$ In this regard it is solicited to wear symbol of Basanta colour.

2) 2/ On 11 th Magh, while joining the ground assembly kindly do carry the card."

Birendra Kishore Manikya took the Manipuri dance and music very seriously and tried his level best to propagate it more and more. The way he blended torch and mridanga is simply awesome and marks the sign of creativity. May be it happened earlier or in later days. The late Manipuri dance gurus Rajkumar Buddhimanta Singh and Thakur Nabakumar Singha spread Manipuri dance in the outer states and both of them did this during the regime of Maharaja Birendra Kishore Manikya, which era saw the brilliant growth in this regard. They became famous from Raj dance guru to teachers in Santiniketan. This has only happened sue to Rabindranatha Tagore. Rabindranath came to Tripura for the first time during the tenure of Radhakishore Manikya (1899). At that time, in order to welcome the poet of the poet a grand feast having raas and Manipuri dance was organised in Kunjaban, an exquisite adjacent city skirt of Agartala. How the maharaja has tried to make the event more grand, a glimpse of that has been mentioned in the essay 'Tripuray Rabindra Smriti' - the welcome dais was made imitating the traditional house of the indigenous people, Tong ghor... From that welcome dais waves of small hills were visible that merged in the horizon. The blue moon sky having the origin in the horizon made the atmosphere more serene. This enchanting ambience was made more elegant by the standing queue of the Manipuri dance artists. Open body, wearing Basanti coloured dress, long scarf on neck of the same colour, pagri on head of the same colour made a soothing scene with the dance step and feet taping with khol, mandira and kartal. Even the audience were also in the same basanti coloured dressed. In this atmosphere both the King and the poet were sitting on the bed of Manjapori Farash. Relevant dance and music, gift of flowers, same attitude of the king and his subject made the mind of the poet filled with joy and wonder.

This is for the first time Manipuri dance enchanted Tagore. In later time also the poet has witnessed Manipuri dance in Sylhet and other places. In order to start dance as a subject in Santiniketan Tagore had asked for experienced Manipuri dance teachers from Maharaja Kumar Brajendra Kishore (Lalukarta). With due consultation with the King Rajkumar Buddhimanta Singh was sent to Santiniketan. It was done by the order of Birendra Kishore. Tagore had also asked to send the wife of Buddhimanta Singha in order to teach weaving to the girls of Santiniketan. Many 
believe that this is how Manipuri dance became world-famous. In later times many Manipuri dance teachers went to Santiniketan - Panganbam Thakur Nabakumar Singha, Rajkumar Chandrajit Singha, Thongam Basanta Singha, Nileshwar Mukherjee etc. On 13 ${ }^{\text {th }}$ August, 1923, with the death of Maharaja Birendra Kishore his son Bir Bikram Kishore ascended to the throne. Practice of Manipuri dance drama did not stopped in royal meeting, royal palace, royal house etc. Not only that, it was spread outside the boundary of the royal palace and reached to the relatives and related person to the palace. Manipuri kirtan became an essential part of the well-wishing ceremonies of the royal palace. Maharaja BirBikram was the age of 15 when he became the king of Tripura on 1923. His traditional coronation held in 1928. During his coronation Manipuri kirtan did a procession from the Ujjayanta palace to the coronation dais. The then Bengal's Governor Jackson Sahib was present in that ceremony as a guest. In the year 1939, Maharaja went for a trip in Europe and also visited America, Australia, Singapur and came back to his state via sea route. In order to mark the event of the King's return Khubak Cholom (dance performed with kartal) was organised by the male Manipuri. Right at that moment, Khubak Cholom was transformed into Kartal Pala in association with the dance gurus. In the year, 1909 Maharaja Churachand Singh came to Tripura from Manipur to serve pram to his relatives and grandmother Ratnamanjuri. Even at that time also many foreign dignitaries came. In order to hail them a magnanimous Manipuri cultural programme was organised. During the time of Maharaja Bir Bikram Kishore Manikya inside the royal palace and in around of the said palace many dance and music programmes were held. It is heard that inside the palace there were three different stages. Many dance, music and drama were performed on these stages. The attendants of the palace participated in the events. In the 'Tripurar Manipuri Praja' the writer more elaborately states that - "In 1344 Tripurabda (1924 A.D.) Bipralabdha were held thorough Manipuri dance in that same way. The songs compiled and published in the book are being mentioned in the script.

With the inspiration of Sri Srimati Eldest Maharani Mahadevi

First Singer

Composed by Maharaja Kumari Srila Srimati Ila Devi

Bipralabdha

Capital Agartala

Year 1344 Tripurabda.

In the dance competition not only expertise of dance were exhibited but along with there was dress, make up, many technical aspect etc. Once Bir Bikram gave the dancer red lotus made out of paper, and a torch light was hidden inside it and during the dance that flower used to illuminate red colour. Elder Mother Maharani ordered silver coloured vessel from Bombay, and torch was inserted in that, and with the power supplied from battery that vessel used to shed pearl like colour.

After visiting England and America Maharaja Bir Bikram came back to Tripura. Along with him came some foreign sahib guides. To celebrate that Maharaja organised 'Khubak Ishei' in the palace. Manipuri dancers danced only with hands. Suddenly from the waist belt (Khwangyet) kartal came out and kartal dance started. With the sound of kartal, grave sound of Mridanga like roaring of the thunder, a mesmerising situation was created. All the spectators were startled to see such a thing."

So far we have come to know that Maharja Bir Bikram was himself a cultural person and also had the full quality of an artist. Only through dancing one cannot become an artist, to be a genuine artist one must have taste of dance and zeal to do something new corresponding to the knowledge. These qualities were present in Maharaja. The events during his tenure held inside the royal house was spectacular and eye catching. The writer has also mentioned that - “On 17th May 1947 (2nd Joistha, 1337 Tripurabda) the king died. For his last sacred rituals the king of Manipur Budhchandra Singh came to Agartala. Along with him came a team of Natasankirtan singers and his Ninigthem Pala. Whenever the Manipuri kings came to Agartala, they have brought singers and dancers along with them. This is almost like today's cultural transaction. When Maharaja Churachanda (1891 - 1941) visited Agartala for the first time (15 th January 1909 A.D.) during the time of Radha Kishore Manikya along with him he brought a team of kirtan players, and famous in Manipur Shagol Kangjei (Polo) Thang-ta and Mukna's (Wrestling) team. The exhibition held in the then Khosbagan ground. For the last sacred ritual a huge stage was made on the north side of Ujjayanta Palace so that Nata Sankirtan could take place. Thousands of audience, devotee, and thinker came there. Oja Natum, legendary Manipuri singer started singing a song in Meghmallar raga. The main Mridanga player was another famous Manipuri personality Oja Samden. Generally in Manipuri rituals 9 to 11 Pala or Singers participate. Suddenly clouds hovered on the place of the Kirtan and rain poured with thunders. Due to heavy storm the stage broke. With difficult effort the sacred pitcher of the Kirtan was saved and later on taken inside the palace and there it completed with full devotion. It is heard that many audience said this happened due to Meghmallar. The beauty, sanctity and delicacy 
attracted the kings of Tripura so much that they considered as their own. The kings of Manipur Garib Niwaz and Maharaja Bhagyachandra themselves accepted the Vaishnab religion and later on subjects showed interest for that. Due to the interest of the Kings of Tripura for Manipuri culture it took a wide shape. Due to the patronage of the kings of both the states Manipuri dance and music has been reached to the world platform. After Maharaja Bir Bikram these cultural practices, festivals gradually slowed down inside the royal mansion. However, the head queen of Maharaja Birendra Kishore Eldest Mother Pravabati Devi continued these for a long time. Due to the wreckage of time, lack of interest Manipuri dance drama has now become a history in the royal palace. But many remember the past. But the practice of these dace drama inside the royal palace not only left a mark on the Manipuri people but also on the other people. In and outside the palace, princes, prince, and kith and kin of the king, elite families it reached. That is the reason on the event of diamond jubilee Manipuri raaslila was held at the house of Ishan Thakur in the year 1953. The event was directed by Maharajkumari Ujjyala Devi. The dancers were Kumari Sarbashri Rajeshwari Devi (Bibi), Jharna Devi, Manika Devi (Munu), Priti Devi (Chunu), Sanchita Devi, Chandramukhi Devi and none of them are Manipuri. The mridanga players were Rajkumar Surendrajit Singha, Raman Singha. The stage design was done by Maharajkumar Sahadeb Kumar Bikram Kishore Debbarma Bahadur, Sri Narendranath Dasgupta, Sri Rana Ananta Jung Bahadur. One of the sons of Maharaja Birendra Kishore Maharajkumar Hemant Kishore Debbarma, who was Sub-divisional magistrate and other office bearers at a time learned mridanga playing traditionally. He arranged Goura Dhumel in Khowai and compiled taal, laya, matra and chanda from Dwadash Rajmen of eminent Manipuri Oja Jadunath so that new learners can easily learn Dwadash Rajmen. He also took enterprise to retain the ideal of Dwadash Rajmen in an exact way he wrote a book called 'Mridanga Lahari.' In this work one of his associate Mridangacharya Fanjenbom Golap Singha of Dharmanagar helped him. This is a wonderful inclusion in Manipuri Mridanga Sastra".

During the tenure of Bir Chandra Manikya the women inside royal house used to converse in both Manipuri and Kokborok. Bir Chandra himself could speak Manipuri language fluently. Though he used to practice poetry in Bengali but he used to talk to his wives in Manipuri. None of his wives knew Bengali. They used to wear Fanek, Inefi etc Manipuri costumes. Their attendants were also habituated in these clothes. The queens and princes used to wear heave golden and diamond jewellery of Manipuri design can be witnessed in many old photographs. Both the Tripuri and Manipuri queens used to wear a unique waist belt loom. The Tripuri and Manipuri queens used to draw flying

birds, flowers, herbs and bushes, animals and design on silk made ria-rignai and fanek-inefi in a brilliant way. The third wife of Bir Chandra Manmohini Devi was the master of this craft. Apart from weaving they were also expert at embroidery. Here in relevance it can be said that common Manipuri housewives are acquainted with weaving. Till $18^{\text {th }}$ century inside the royal mansion Tripuri language was in vogue. In the year 1785 Rajdhar Manikya was associated with the Kings of Manipur due to nuptial affairs with princes and later on many Manipuri people and attendant came here and started speaking Manipuri (Meitei) in royal inner court. At that time the population of Tripura was near about 50 thousand. In general people used to speak Bengali and Indigenous languages. But inside the royal palace people used to speak Manipuri and Bangla. In later timies many kings of Tripura married Manipuri princes and accepted many Manipuri as their Kachhua Wife and as a result inside the royal mansion Manipuri language and culture flourished. The breeze of Manipuri culture started blowing inside the royal house from the time of Second Rajdhar Manikya and with the gradual expansion of the day and increase in Manipuri people in every nook and corner of the palace this culture reached and ultimately became as if its own. This is how Manipuri tradition started flowing in the royal palace.

\section{SOURCES OF FUNDING}

This research received no specific grant from any funding agency in the public, commercial, or not-for-profit sectors.

\section{CONFLICT OF INTEREST}

The author have declared that no competing interests exist. 


\section{ACKNOWLEDGMENT}

None.

\section{REFERENCES}

[1] Adhikari Udainarayan, Socio - Cultural Relations A e New among State in Pre Independence India, Akansha Publication House Delhi, Guwahati, 2010.

[2] Birmangal L \& Rai Pannalal, Itihasher Aloke Tripura - Manipur, Akshar Publication, Agartala, 2007.

[3] Birmangal Wangkhem, Takhengi Puwarida Manipuri, Tripura Bani Prakashani, Datta Super Market, Shakuntala Road, Agartala, 2016.

[4] Chakraborty Dr.Umashankar, Tribal Dances of Tripura, Vyasdev Prakashani, Shakuntala Road, Agartala, West Tripura, 2010.

[5] Das Manoshi \& Choudhury Rebati, Tripura Rebati, Tripura Tribe A Status Analysis, Tribal Research and Cultural Institute, Govt .of Tripura, 2011.

[6] Datta Soma, Manipuri Nrityashaily O Rabindranath Prasanga Tripura, Nava Chandana Prakashani, Ramnagar Road No-2 (West), Agartala, 2011.

[7] Debbarman Suren, Tripura Upojatiyo Adidharma Nrityakala O Devdevi, Jnan Visakhapatnam Bichitra Press, 11Jagannathbari Road,Agartala, 2004.

[8] Dutta Rama Prasad, Tripurar Holi : Rajantapur Thekey Rajpathe, Pounami Prakashani, Hospital Road, Agartala, Tripura, 1999.

[9] Goswami Dwejendra Narayan \& Singha Rajkumar Jitendrajit, Tripurar Manipuri Praja, Tripura Bani Prakashani, Datta Super Market,Shakuntala Road, Agartala Tripura west,2016.

[10] Ibochaoba Haobam, The Pre-World War- II Form of Ras Leela, (L) Haobam Ongbi Shantibala Devi, Uripok Haobam Leikai,Imphal, Manipur, 2009. 